Cummins, I (2019) Social Work and Advanced Marginality in Class, Ethnicity and State in the Polarized Metropolis: Putting Wacquant to Work pp 231-254 


\section{Social Work and Advanced Marginality}

\section{Introduction}

This chapter explores the impact of broader social and economic policies on social work practice. It argues that the increasing inequality and polarisation of modern urban societies that is outlined in the other chapters of this book has had a direct impact on the role of social workers. The chapter begins with a brief outline of the reaction of British Governments to the banking and Eurozone crises of 2008. It then goes on to argue that the introduction of "austerity" the Conservative-Liberal Democrat Coalition Government in 2010 involved not only significant reductions in welfare spending but was a political project aimed at recasting and reducing the welfare state. The chapter then examines social work practice in the context of advanced marginality. It argues that the changes and processes examined in the other contributions have resulted in an environment where social work has an increasingly disciplinary role. The impact of neoliberal welfare retrenchment compounded by austerity is that social work practice is increasingly experienced by service users as negative or punitive interventions in their lives. This is, despite the profession clear ethical stance being one that is committed to empowerment

Neoliberalism, Austerity and the context of Social Work practice

The development of economic and social policy since 2008 and the adoption of policies of austerity since 2010 are the consequence of responses to the banking and Eurozone crises. The initial reaction of the Gordon Brown-led Labour UK Government to was to follow a Keynesian model of economic management. Alongside the bailing out of the banks at an estimated cost of $£ 141$ billion (Oxfam, 2013) demand in the economy was stimulated by a programme of infrastructure projects and a reduction in Value Added Tax (VAT). In the period 2008-2010, the poorest fifth of the UK population saw an increase of 3.4 per cent in their incomes (Oxfam, 2013). The election of the Conservative-Liberal Democrat Coalition 
Government in 2010 saw an end to this approach and the introduction of a range of policies including welfare "reforms" and retrenchment in public spending that came to be known as "austerity". The failure of the Conservatives to win an overall majority led to the formation of a coalition government. The UK political and voting systems are structured in such a way to avoid such outcomes. There was a period in the late 1970s where Labour and Liberals had entered into a political arrangement but that fell short of a coalition. This was the first formal coalition government in the UK since World War II. One of the reasons given for the coalition was the argument that the country was facing a national emergency because of the parlous state of the public finances. The Coalition Government presented Greece as a constant reference point for the need for these changes and reduction in welfare spending (Cameron, 2010). This is particularly significant in the UK context where the Greek welfare state and pensions are consistently portrayed in the media as allowing Greek public servants to retire early on generous stipends. The real issue in Greece has been the fact that elites have been successful able to avoid paying tax. Blyth (2013) notes that austerity, although presented as an emergency solution to a national and international crisis, is actually a modern variant of well-established monetarist approaches. Krugman (2015) concluded the real aim of austerity was a nakedly political one to shrink the state and reduce social welfare provision not just as a temporary measure but permanently. The implications for this approach for social work and social work practice are examined below.

Neoliberalism is an overtly political project but presents itself as a technocratic economic one (Wacquant (2008, 2009a and 2009b). The social and political aim of neoliberalism has been to remove the main provisions and protections of the social state established in the post war social democratic settlement (Giroux, 2011). The UK Coalition Government used the language of a national emergency to justify cuts in welfare provision that represented the biggest cut in state spending in the UK since World War II (Crawford, 2010). A further round of cuts in services totalling $£_{12}$ billion are, at the time of writing, planned by the current Conservative Government. 
In addition, those politicians leading Brexit are clearly ideologically committed to a residual welfare state and the removal of social protections for workers (Dunt, 2016). The Coalition Government abandoned a neo-Keynesian approach. There followed a series of cuts to local authority spending and the funding of social programmes. The Coalition argued that the fiscal crisis was the result of profligate Government spending - particularly on welfare - and this need to be curtailed to bring down the national debt(Cummins, 2018).

Beatty and Fothergill (2016) demonstrated that the impact of the above reforms on local government was that Local Authorities in the poorest areas have experienced the greatest financial losses. This has created a pincer effect in that the demand for services and support have increased at a time when these very services are facing enormous financial pressures. Given the geographical disparity in the impact of austerity, it is important to note that these reforms disproportionately effect younger people, women and children alongside minority ethnic communities ( Emejulu and Basel, 2016 and Crossley, 2017). The impact of austerity is often hidden from the wider public view. Decisions such as the closure of a library or the increase in costs for leisure activities might be a short report in a newspaper or on local news. However, the community impacts are far reaching. Sure Start Centres were a key element in New Labour's policy to tackle child poverty. The centres offered families access to services including childcare, healthcare, parenting classes, job skills and playgroups. Since the start of the period of austerity in 2010, over 350 Sure Start Centres have closed across the country (https://www.theguardian.com/society/2017/feb/o2/sure-start-centres-300-closedsince-2010).

In the Weight of the World (1999), Bourdieu argued that the American ghettos and their citizens had been neglected by a range of state institutions - apart from representatives of the penal state. Areas of advanced marginality can thus be characterised as sites of absence - key state institutions fail to function or have a positive impact on the lives of citizens. The impact of austerity has been to create a 
similar processes in the UK with state intervention even from welfare agencies being experienced as increasingly punitive.

Anti- welfarism

One way to approach an analysis of austerity and its impact is to view it as a class project with the clear aim of completing a recasting of the welfare state. However, there is an alternative which sees these processes as more fragmented involving continual struggles across political, economic, symbolic and social spaces Wacquant ( 2013 ). The response of the Conservative-Liberal Coalition in the UK was to use the banking and fiscal crisis as a base, from which, to enact a series of policies that will have the greatest impact on the poorest members of society. Before these current attacks on the social state, the Right has been engaged in a long term attack on the notion of welfare provision. There is a long history of demonising the poor and representing poverty as the result of moral failings rather than structural inequalities (Welshman, 2012). Crossley (2017) notes that from Booth onwards, areas of deprivation have been represented in very similar terms to lands conquered by colonialists. For Booth, the East End of London was a mysterious and dangerous place - “Darkest England”. Booth's (1890) maps of poverty are also maps of morality - the poor are also idle, feckless and sexually promiscuous. In addition, the large families of the poor thus posed a threat to the standing of the nation. A belief in eugenics and social hygiene to ensure that society was not producing too many 'imbeciles' or 'inadequates' was a commonly held and respectable one. Public figures such as George Bernard Shaw and Winston Churchill were both in favour of these policies (Carey, 2012). Perkins (2016), inspired by Eysenck, put forward the proposition that the welfare state provides incentives for the least capable (that is, the poorest) parents to have more children. Caspi et al (2016) argued that it was possible to identify future criminals and those who will place the greatest demand on welfare services by means of a simple test at the age of three. This is junk science but note that in being in receipt of welfare and criminality are used almost interchangeably. These current views have echoes of the early eugenicist positions. 
However, they are not equivalent and certainly do not have the political influence of the eugenics movement of the early twentieth century.

Since the early 1990s, the Right has mounted a protracted "war of position" against the key features of a universalist welfare state (Garrett, 2017). One key element of this is the way that the term welfare has come to have overwhelmingly negative connotations. Wacquant (2009a) traces the nexus between academics, right wing think tanks and op-ed in Conservative newspapers that have helped to shift the meaning and usage of the term. Slater's (2018) analysis of the development and use of the term "sink estate" is a case study analysis of these processes. In the American context, welfare has become a "dog whistle" term (Haney- Lopez, 2015) which politicians can use to make racist claims and statements whilst at the same time claiming that they are not talking about race. It also serves to remove the ghetto from any political, historical or racial context. Mead (1992) and Murray (1990) present poverty as a moral issue in the sense that poverty is the result of the moral failings of those living in poverty. Mead (1992) does contain a more paternalist strain which leads to a call for some limited state action. For Murray (1990) poor people make poor choices and are then rewarded for them by the welfare state. Alongside the issue of the creation of dependency and the idea that welfare rewards individuals for their anti-social behaviour, it is regarded as costing too much money. The condition of the public finances in 2010 thus proved to be an opportunity that was too good to miss for those who had been opposed to the fundamentals of a universalist welfare system.

Murray (1990) has been, possibly the most prominent and vocal proponent of the underclass discourse. The underclass discourse makes the claim that the welfare state creates and maintains dependency because generous benefit payments mean that individuals are spared the discipline of the market. In Murray's (1990) analysis the welfare state is the prime driver of other social problems, crime, drug misuse and a wide range of other social ills. Wacquant (2009a) highlights that the term has been used as a catch all phrase that has little, if any, sociological value. However, within popular and policy making discourse it remains, despite there being no clear 
definition, a very powerful term. There is a feedback loop in play here. Sampson (2012) argues the portrayal of certain areas as urban wastelands scarred by drugs and crime is not only misleading but also serves to reinforce pre-existing inequalities and marginality. Slater (2012) argues that the underclass hypothesis inevitably constructs the poor in eugenicist terms. Alongside attacks on the fundamental notions of a social state, there has been a demonising of those living in poverty. A series of UK reality TV programmes such as Benefit Street claim to show the reality of life in the poorest neighbourhoods in the country. These programme makers claim that these shows are social realism or attempts to show areas of life that mainstream TV ignores. The results are far from this and simply invite the wider audience to ridicule the participants. Demonization of those living in poverty is widespread across popular culture and the tabloid media (Tyler, 2008; Shildrick and MacDonald,2013 Jensen, 2013).

The roots of the portrayal of the modern urban poor can be traced back in a fairly direct line to Booth's view of the East End as another colony whose wretched inhabitants needed rescuing from themselves (Crossley, 2017). In 2013, a report from the Baptist Union of Great Britain and a coalition of churches outlined what it regarded as deeply entrenched myths that surrounded the "poor". These were as follows the "poor" are

lazy and don't want to work;

- $\quad$ addicted to drink and drugs;

- $\quad$ are not really poor, but simply are incompetent in managing their money;

- $\quad$ on 'the fiddle';

- $\quad$ have an easy life;

- $\quad$ prompted the 'deficit' which was causing the 'austerity' measures impacting on everyone 
Apart from the final one that is specific to the context of austerity, these are the description of the "poor" that have been passed down across the generations.

Austerity politics has seen a hardening of social attitudes. Sayer (2015) notes that the financial crash, whilst leading to some limited social criticisms of bankers, has also paradoxically led a hardening of anti-welfarism. This is the result of the way that the Coalition government was able to construct and successfully maintain a narrative that the crisis in the public finances was the result of welfare spending. There is an important proviso here in that welfare was very much referring to benefits paid to those who were out of work rather than pensions. Jensen and Tyler (2015, p 471) argue that the result has been the development of a new form of political economy which involves what they term a 'hardening anti-welfare commonsense". The tabloid press has always reported examples, however extreme or unrepresentative they may be, from the benefit system as a way of undermining wider support for the system. This is a crucial element of the construction and maintenance of an anti-welfare discourse. Jensen and Tyler (2015) show the way that the press used the convictions of Mick and Mairead Philpott for the manslaugther of their six children, in an arson attack, in this way. Even before these appalling offences, Mick Philpott was a regular figure in the tabloid press and on TV. He appeared in a programme Ann Widdecombe Versus the Benefits Culture (2007) alongside a former Tory Minister, herself a regular on reality television. Widdecombe was tasked with finding him a job. Philpott is held up in the press and on TV as representative of all those in receipt of benefits. He is, of course, nothing of the sort. Philpott, the father of 17 children, planned an arson attack that resulted in the death of six of his children. Yet he was portrayed in the tabloid press as the product of a bloated welfare state. The reporting of the welfare system has had a vital role in the creation of a climate of hostility towards the very institution of the welfare state. These debates take the work of Murray as a starting point or given so that the issue to be solved is not poverty, but welfare dependency (Peck and Theodore, 2010). Jensen and Tyler (2015) show that these atypical families, such as the Philpotts, by their repeated appearance in the media help to sustain a narrative of the indulgent, profligate welfare state. The Philpotts can hardly be regarded as a typical family but the constant media 
references to them makes them appear much more common than they actually are. At the time of the case, Department of Work and Pensions (DWP) stated that there were ten families in the country where there were thirteen or more children (Jensen and Tyler (2015)

Stigma, shame and advanced marginality

Goffman (1963, p3 ) described stigma as an attribute that is "deeply discrediting". One of the impacts of stigma is to reduce the holder or the stigmatised person "from a whole and usual person to a tainted or discounted one". Tyler (2018) considers the political economy of stigma. In examining its impact, it is vital not just to examine the individual psychological effects of stigmatising discourse. In this case, these discourses are part of a neoliberal political project that seeks to undermine broader social and political support for the institutions of the welfare state. It has to be acknowledged that, for example, the "underclass" discourse has become a deeply entrenched one in media portrayals of welfare systems, as illustrated above. At the same time as recognising the powerful nature of stigmatising anti welfare discourse, it should be recognised that class identities are fluid, complex and often contradictory (Friedman and Savage, 2017) Communities, individuals and groups respond to, challenge and redefine these labels( Solomons, 2014).

Poverty has become increasingly spatially (and racially) concentrated. Wacquant (2009a, 2009b) outlines how communities have been denied access to decent housing, education and employment opportunities and a safe and secure community. Advanced marginality captures these processes, the term is a counter to underclass with its eugenicist overtones. Advanced marginality is an endogenous feature of neoliberalism (Wacquant, 2016). It should be viewed as an inevitable outcome of the attacks on the features of the social state that had been established by post war Keynesian economic and social policies. The post World War II welfare state was based contractual and reciprocal notions of the relationship between the state and citizens. For example, unemployment benefit was designed to cover short period of unemployment. This was underpinned by an assumption that the unemployed 
worker would look for work but also that government economic policy would produce full employment (Timmins, 2017). There were clearly a number of problems with the exclusionary nature of the post war social democratic settlement. It was based on a series of gendered, racial and class assumptions. Neoliberalism produces inequality, social and racial exclusion alongside an expansion in precarious employment (Standing, 2011). The final element of these processes is the expansion in the penal state. The USA and the UK have both seen huge expansions in the use of imprisonment ( Gottschalk, 2006, Alexander, 2012 Cummins, 2017 Simon, 2014. Prisoners are overwhelmingly young men from poor, marginalised urban backgrounds and neighbourhoods. This fact adds to the stigma that such communities already face (Clear, 2009 and Drucker, 2011) .

Link and Phelan (2001) argue that stigmatisation reflects the dynamics of social, economic and political power and capital. The political economy of stigma involves the labelling of individuals and the construction of stereotypes. These processes result in disapproval, rejection and discrimination. Dorling et al (2007) noted that before the economic crisis in 2008, the gap in inequality was already at its widest for 40 years. As inequality has increased so the representation of those living in poverty group has become more vitriolic. An analysis of stigma related to class position has to include popular culture and representations of marginalisation. Inequality is not simply a matter of economic position; it is concerned with cultural and symbolic representation. These are important issues to consider when examining the contemporary role of social workers as the majority of social work takes place within marginalised communities.

The habitus of social work

Bourdieu saw social workers and other public sector workers as having to face two ways at the same time in their fight for social justice (Emirbayer and Williams, 2005, Garrett, 2007. The first was clearly to work alongside service users to tackle the 
barriers they face to full citizenship. This involves challenging other state agencies and bureaucracies. At the same time, social workers seek to challenge the imposition of new systems and policies within the bureaucracies, in which, they practice. This tension can be, at times, creative but also it should be acknowledged as a source of frustration. Social work is in a liminal position between the state and individuals, families and marginalised communities. The greater the distance between the aims of government policies and the stated values of social work, the greater these tensions become. The habitus of social workers will retain some key elements whatever area they work in. However, there will be differences. For example, the habitus of a mental health social worker will reflect their education, training and practice experience. It is likely to include critical perspectives towards institutionalised and coercive forms of mental health care. In addition, it will recognise the historical, social, political and cultural factors that combine to produce the current system (Morriss, 2016a, 2016b and Cummins, 2018b).

Social work is a broad term that can encompass a range of welfare services. In the analysis of social work, the focus is generally on statutory services - i.e. services that local authorities or central government have a legal obligation to provide. Social work thus encompasses a range of activities and interventions in the lives of citizens. One of the fundamental debates in social work is focused around the inherent tensions within the social work role. The International Federation of Social Workers (IFSW) definition of social work states:

Social work is a practice-based profession and an academic discipline that promotes social change and development, social cohesion, and the empowerment and liberation of people. Principles of social justice, human rights, collective responsibility and respect for diversities are central to social work. Underpinned by theories of social work, social sciences, humanities and indigenous knowledge, social work engages people and structures to address life challenges and enhance wellbeing. (www.ifsw.org.) 
Bourdieu's (1998) outlined what he termed the Right and Left Hand's of the state. On the Right hand were agencies concerned with social order - the Police, Courts and Prisons. On the Left Hand were, what we might term welfare agencies. In Bourdieu's conception of the two poles of the State, the above definition of social work places it very much on the Left Hand. Social work as a profession sees itself as concerned with fighting for social justice and challenging inequality whether it is experienced on an individual or institutional level. Garrett (2007) has highlighted that Bourdieu's conception of the State, if it is applied in a reductionist fashion, ignores the complexity of the role of state agencies. Social workers are part of systems that involve the exercise of legal powers to intervene in the lives of citizens against their will - for example in the fields of child protection and mental health. In the same way, agencies such as the police, which Bourdieu places on the Right hand of the State, also play a welfare role. For example, mental health work is increasingly an important part, possibly as much as twenty per cent, of police work in the UK(Sainsbury Centre 2008). It is, thus, increasingly difficult to caterogise the role of a number of state agents in a binary fashion - welfare v. punitive or disciplinary interventions.

Social workers are classic "street level bureaucrats" (Lipsky, 1980). There are a number of similarities between current political and economic circumstances and those when Lipsky (1980) wrote his study. It was written against a background of financial retrenchment. The city of New York had just gone bankrupt. He argued "street level bureaucrats" -police officers, welfare workers and social workers have a key role in enacting government policies. The complexities of these welfare and other policies are played out in the interactions between individual citizens and the state employees in offices and houses across the country on a daily basis. Lipsky (1980) acknowledges that this means that public workers are thus in a position where they can subvert or resist policies (Barnes and Prior, 2009.) Bourdieu et al (1999 p 184) see this as a form of collective double consciousness. Social work is thus "shot through with the contradictions of the State". Its professional value base commits social workers to a set of progressive values based on notions of human dignity and social justice. At the same time, many individuals and families experience social work interventions as harsh and punitive or as overriding their 
rights and wishes. These tensions are played out at both the individual and organisational level. One of the myths of social work is that all social workers are committed to progressive or radical politics and social policies. This is not necessarily the case. However, social workers will often find themselves in conflict with the aims of particular government social policies.

One of the key arguments that is put forward here is that the impact of neoliberal welfare retrenchment and austerity is that social work is the increasingly being experienced by service users and marginalised communities in negative terms or as punitive. The broader context means that what Howe (2013) terms the social space ie the scope for individuals workers to act- becomes smaller. In Lipsky's (1980) terms the scope for discretion is reduced. These pressures lead to contact with social work agencies being increasingly experienced as punitive rather than a supportive (Fenton, 2014, and Gupta, 2015). This is not to say that individual workers act in a particular fashion. It is rather to highlight the impact of increasingly managerialist work cultures where a risk paradigm dominates (Webb, 2006). These, combined with a period of austerity and financial cuts, mean that access to services becomes more and more restricted. The ethical core of social work becomes marginalised if it is regarded as a bureaucratic or technocratic exercise (Bauman, 2000). He suggests that the more that the moral and essential human aspects of care are masked or swamped in rules and regulations, the greater the distance between practice and the original ethical purpose (Bauman, 2000).

Many of the developments in social work education and training follow a scandal or public outcry (Butler and Drakeford, 2006). Child protection inquiries and their aftermath are a consistent feature of the media reporting of social work (Warner, 2015). This is despite the fact the findings of Inquiries and Serious Case Reviews (SCRs) tend to be broadly similar, particularly highlighting poor communicaiton between agencies. Following the death of Baby P in 2007 ( Jones, 2010, Shoesmith, 2015) there was a series of reviews of social work that called for root and branch reform of the approaches taken to the recruitment and education of social workers. 
Munro (2010) argued that it is simply impossible for social workers and the wider society to ensure that all children will be safe at all times and in all circumstances. At first glance, this might appear to be something of a council of despair. It is not. It is rather an attempt to recognise that there are limits to the protections that public services can claim to afford. Warner (2015) demonstrates that the political and emotional climate, in which child protection takes place,means that this is a statement that a politician will almost certainly never make. The Professional Capabilities Framework (PCF) was drawn up to provide an over-arching framework for the professional standards for social workers in England. The PCF (https://www.basw.co.uk/pcf/) was developed by the Social Work Reform Board which was established following the death of Baby P. The PCF is divided into nine domains including, for example, professionalism, values and ethics and knowledge. The PCF then outlines what should be expected of social workers at each stage of their career from entrant to principal social worker.

Rights Justice and Economic Wellbeing is one of the domains of the PCF. At the level of qualified social worker an individual should provide evidence that they Enable and support people to consider and pursue a range of options that may enhance economic status (through access to education, work, housing, health services and welfare benefits). There is clearly a danger that the PCF is viewed as simply a managerialist tool rather than an integrated ethical framework. The nine domains can be presented as distinct boxes that have to be ticked so that a student or qualified social worker can move to the next level. The alternative is to see the PCF as a base from which to build relational forms of practice Human interactions cannot be separated from the societal structures and institutions in which they are embedded and take place (Lipsky, 1980). The shifts in the nature of social work practice cannot be divorced from both the economic policies of austerity but also the anti-welfarism that underpins them. Cummins (2018) argues that the PCF can be the basis for a more engaged form of social work practice.

Webb (2010) suggests that social work is often defended on the grounds that it performs a role in protecting and supporting vulnerable people or groups. It is thus a 
response to the failings of the market. As Webb (2010) notes, social work and welfare systems have a redistributive function. These services are usually funded from taxation. This means that some contributors are unlikely to use all of the services, or if they do it will be for very short periods. Critics of social work and the welfare state more broadly from both the left and the right argue that this masks the fundamental nature and role of welfare systems. For the left, social work for all its rhetoric of empowerment and inclusion is essentially a disciplinary activity that helps to shore up rather than challenge structural inequalities. For the right, social work is part of the bloated state bureaucracy that creates dependency and stifles individual freedom.

Social Work in the polarised metropolis.

Wacquant (2007) coined the term 'territorial stigmatisation' - to describe the impact of neoliberal economic and social policies. He concludes that they lead to:

... forms of poverty that are neither residual, nor cyclical or transitional, but inscribed in the future of contemporary societies insofar as they are fed by the ongoing fragmentation of the wage labour relationship, the functional disconnection of dispossessed neighbourhoods from the national and global economies, and the reconfiguration of the welfare state in the polarizing city. (pp 66-7)

The majority of social work practice takes place in areas of "territorial stigmatisation" i.e. communities and neighbourhoods that are described above. The state and state actors have key roles to play in reducing the social impact of economic inequality (Esping-Andersen 1999, Gallie and Paugan, 2000). One of the key features of neoliberalism and austerity is the denial of this role. The "nightwatchman state" as outlined by Nozick (1974) is limited to the roles of providing a legal framework that enforces the law of contracts and the protection of individual citizens via the Criminal Justice System (CJS). 
As outlined above, there is a tension between the declared ethics and values of social work as a profession and the context in which practitioners carry out their roles. These tensions and contradictions are not new and have been a feature of social work and modern welfare regimes since their emergence as a response to modern urban capitalism ( Fox-Piven and Coward, 1978). However, the retrenchment that has taken place under successive UK governments following neoliberal influenced economic policies and then austerity has seen a shift in the nature of the social work role. I will examine this shift using the example of child protection work.

Donzelot (1979) noted that poorer families have consistently been subject to greater state surveillance than wealthier ones. This, in turn, leads to an increased likelihood of some form of state intervention. It is important to make clear that living in poverty cannot be equated with parental neglect. Featherstone et al (2014) show that poverty is increasingly cast as a parental neglect. This results in the conduct and oreintations of parents - overwhelmingly mothers - rather than structural issues, being the focus of examination. Hayes and Spratt (2014) see an increasingly forensic or investigatory turn in child protection. The danger is that a model of practice develops where intervention occurs - no support being offered - at a time of acute crisis, and is of the most dramatic kind, that is, the removal of children from parents. Bywaters et al (2014) outlined that the abuse and neglect that the state investigates and responds to overwhelmingly occurs in the context of families and communities living in poverty. The responses of the state thus become part of a culture that is shaming. As social work systems become more bureaucratised and dominated by risk paradigms, the tensions between the expressed value base and the practice context are heightened.

Child welfare has increasingly become a site for the reproduction and reinforcement of inequalities. The work of Bywaters et al (2015) and Bilson and Martin (2016) highlights the interplay between the increase in inequalities, the retrenchment in general welfare provision and social support and the punitive turn in child 
protection. Bilson and Martin (2016), using a Freedom of Information request, obtained data from seventy-five per cent of all Children Service's Departments in England. This research demonstrated that there has been an upward trend in the number of referrals to, and investigations by, Children's Services. The impact of the 'politics of outrage' following the 'Baby P' case would account for some of the increase (Parton, 2012, 2014; Warner, 2013). However, these upwards trends represent a shift in the balance between marginalised families and the state. Bernard (2017) has examined the way that richer families where there may be concerns about parenting are able to use their social privilege to effectively opt out of services.

Bywaters et al (2015), using official data from the Department for Education, show that a child living in Blackpool, one of the poorest towns in England was, eight times more likely to be in the care of the Local Authority than a child living in Richmond: an affluent borough of London. Another way of examining the extent of the intervention of social work in the lives of children and families is the rate of the use of child protection plans (CPP). CPPs are drawn up by professionals where there have been significant concerns about the welfare of a child. In 2012, the Local Authority with the lowest rate of CPPs was Milton Keynes. There were 8.9 CPPs per 10,000 children. The Local Authority with the highest rate was Torbay - a significantly more deprived area - where the rate was 114.8 per 10,000. Thus Torbay social workers and other agencies were nearly thirteen times more likely to intervene in this fashion in the lives of local children and families. There will inevitably be some variations but these are huge.

Bywaters et al (2015) work shows that families in the most deprived and marginalised communities are much more likely to experience social work intervention.These interventions, despite the best efforts of social workers in their face to face contacts with parents and carers, are increasingly punitive rather than supportive. The state has reduced funding to agencies and voluntary sector organisations and other groups that can act as a buffer between it and individuals and families. At the same time, in this arena the state is intervening more often in the lives of children and families, in increasingly punitive ways. 


\section{Conclusion}

Neoliberalism is a political, economic and class project that has at its core a view that the "market" and the alleged disciplines of the market have to be applied across as many areas of society as possible. This flooding of the market into all areas means that other values such as mutuality, reciprocity and a respect for the individual are pushed to the margins, or struggle to survive in a hostile environment. In the neoliberal schema, markets reward success. In a neatly circular argument, these rewards are always justified because they are determined by the market. Success is always seen in monetary terms and is individual in its nature. In addition, success is based on individual effort, skill or vision or a combination of the three (Raco, 2012). 
These core beliefs are at the heart of the neoliberal distrust in the modern welfare state. From this perspective, the state and its bureaucracies are naturally inefficient. This anti-statism is, perhaps, most apparent in attitudes towards the welfare state. It is characterised as monolithic and dependency producing. It rewards or actively encourages anti-social behaviour. The final argument against the welfare state is that it costs too much and that it is paid for out of taxation. The burden of that taxation falls on the middle and upper classes who are least likely to use these services. These trends came together under the umbrella of 'austerity',. This is a political project to reduce the size of the welfare state.

The UK has become a more divided and polarised society over the past thirty years. Alongside this increase in inequality, the public discourse has harshened, fuelled by tabloid media attacks on those living in poverty. The work of Tyler (2008), Jensen and Tyler (2015) and others demonstrates the ways in which tabloid media and reality TV programmes have helped shape an anti- welfare, anti-poor discourse. The advent of reality TV and poverty porn has also created an environment which presents those living in poverty and their daily struggles against this marginality, as a form of entertainment.

Social work as a profession is committed to the principles of social justice. However, it would be naive to ignore the fact that it has a role in the policing of the poor. The tensions that arise from these roles are played out on a daily basis by individuals and organisations. It is simply not possible, however much we might like to, to deny this reality. The discussion of the trends in child protection social work have been used here as an illustration of the ways, the "centaur state" has developed. For elites, the frontiers of the state have been "rolled back". This is not the case for those living in poverty (Wacquant, 2012, Flint, 2017). The penal state has increased in the size, scope and the harshest of its regimes (Wacquant, 2010, Cummins, 2017). Offenders are now seen as sites of risk who require management rather than fellow citizens who require intervention from social programmes to assist them to tackle mental health, drug or alcohol issues or the impacts of being subject to abuse. At the same time, the experience of claiming or receiving welfare payment has been increasingly punitive. 
Individuals are subject to conditions alongside stigmatising and often dehumanising process that overall have the impact of "criminalising poverty".

White (2009) argues that since the 1980s, changes have led to social workers feeling disillusioned and under siege. Warner (2015) demonstrates that these feelings have intensified following the political exploitation of the death of 'Baby P'. It is important to recognise that there is scope for social workers, both as individuals but also as a collective profession, to resist or challenge these developments. The core values of social work are ones that need to be restated and re-enacted on a regular basis. British Association of Social Workers (BASW) UK, the professional body for social workers, has been prominent in its campaign highlighting the impact of austerity and challenging policies. Lipsky's (1980) work is important here as he recognised that there is always scope for "individual street level bureaucrats" to act and exercise discretion. Despite the managerialist turn social work remains, at its core, about building and maintaining relationships. It is these relationships which can form the basis for working with service-users to tackle the barriers that they face to the enjoyment of full citizenship. White (2009) argues there are two potential modes of challenge to the shifts in social work. She terms these 'resistance through distance' and 'resistance through persistence'. "Resistance through distance' sums up processes that Lipsky highlighted whereby social workers and others become a policy making community. Individuals on the ground create a space in which to practice in a way, that they feel is more compatible with their own and the broader professional values. "Resistance through persistences" are the processes, by which social workers use their expertise, skills and knowledge to challenge decision-making and hold managers to account as a means of advocating on behalf of service users. Both are required if social work is to maintain its position as a critical voice. 


\section{References}

Alexander, M. (2012) The new Jim Crow: Mass incarceration in the age of colorblindness, New York, NY: New Press

Barnes, M. and Prior, D., 2009. Examining the idea of 'subversion'in public services. Subversive citizens: Power, agency and resistance in public services, pp.3-16.

Bauman, Z., (2000) Special essay. Am I my brother's keeper?. European Journal of Social Work, 3(1), pp.5-11.

Beatty, C. and Fothergill, S., (2016) The uneven impact of welfare reform: The financial losses to places and people. Sheffield Hallam University.

Bernard, C (2017) An Exploration of How Social Workers Engage Neglectful Parents from Affluent Backgrounds in the Child Protection System https://www.gold.ac.uk/media/documents-by-section/departments/socialtherapeutic-and-comms-studies/Report---Neglect-in-Affluent-Families-1-December2017.pdf

Bilson, A. and Martin, K.E., 2016. Referrals and child protection in England: One in five children referred to children's services and one in nineteen investigated before the age of five. The British Journal of Social Work, p.bcwo54.

Blyth, M. (2013) Austerity: History of a dangerous idea, Oxford: Oxford University Press

Booth, W. (1890) In darkest England and the way out, International Headquarters of the Salvation Army.

Bourdieu, P. (1998) 'The left hand and the right hand of the state', P. Bourdieu (ed) Acts of resistance, pp 1-10.

Bourdieu, P. et al (1999) The weight of the world: Social suffering in contemporary society Cambridge: Polity Press.

Butler, I. and Drakeford, M., (2006). Scandal, social work and social welfare. Bristol Policy Press

Bywaters, P., Brady, G., Sparks, T. and Bos, E. (2014) 'Child welfare inequalities: New evidence, further questions', Child \& Family Social Work 
Bywaters, P. (2015) Inequalities in child welfare: Towards a new policy, research and action agenda British Journal of Social Work, vol 45, no 1, pp 6-23.

Cameron, D. (2010) Prime Minister's speech on the economy

https://www.gov.uk/government/ speeches/prime-ministers-speech-on-theeconomy

Carey, J. (2012) The Intellectuals and the masses: Pride and prejudice among the literary intelligentsia 1880-1939, London: Faber \& Faber.

Caspi, A., Houts, R.M., Belsky, D.W., Harrington, H., Hogan, S., Ramrakha, S. et al (2016) Childhood forecasting of a small segment of the population with large economic burden Nature.

Clear, T. (2009) Imprisoning communities: How mass incarceration makes disadvantaged neighborhoods worse, New York: Oxford University Press.

Crawford, R. (2010) Public services: serious cuts to come.Emergency Budget June 2010 briefing - Institute for Fiscal Studies, London, 23 June 2010, p9 [online] http://www.ifs. org.uk/budgets/budgetjune2010/crawford.pdf

Crossley, S., (2017). In their place: The imagined geographies of poverty. London Pluto Press

Cummins, I., (2017). Social work and the penal state. European Journal of Social Work, 20(1), pp.54-63.

Cummins, I (2018a), Poverty, Inequality and Social Work Bristol Policy Press Cummins, I (2018b) Mental Health Social Work Reimagined Bristol Policy Press Donzelot, J. (1979) The policing of families, Baltimore, MD: Johns Hopkins University

Dorling, D., Rigby, J., Wheeler, B., Ballas, D., Thomas, B., Fahmy, E., Gordon, D. and Lupton, R., (2007) Poverty, wealth and place in Britain, 1968 to 2005. Policy Press for the Joseph Rowntree Foundation.

Drucker, E. (2011) A plagues of prisons: The epidemiology of mass incarceration in America, New York: New Press 
Dunt, I., (2016). Brexit: What the hell happens now?. Tonbridge Canbury Press.

Emirbayer, M. and Williams, E.M., (2005) Bourdieu and social work. Social Service Review, 79(4), pp.689-724.

Emejulu, A. and Bassel, L.(2015). Minority women, austerity and activism. Race \& Class, 57(2), pp.86-95.

Esping-Andersen, G., (1999) . Social foundations of postindustrial economies. Oxford University Press.

Fenton, J. (2014) Can social work education meet the neoliberal challenge head on?' Critical and Radical Social Work, vol 2, no 3, pp 321-55.

Fletcher, D. and Flint, J. (2018,) 'Welfare conditionality and social marginality: the folly of the tutelary state?', Critical Social Policy.

Flint, J., (2017) Encounters with the centaur state: advanced urban marginality and th pratices and ethics of welfare sanctions regimes. Urban Studies.

Friedman, S. and Savage, M., 2017. The Shifting Politics of Inequality and the Class Ceiling. Renewal: a Journal of Labour Politics, 25(2), p.31.

Gallie, D and Paugan, S (2000), Welfare Regimes and the Experience of Unemployment in Europe. Oxford: Oxford University Press

Garrett, P.M. (2007) Making social work more Bourdieusian: Why the social professions should critically engage with the work of Pierre Bourdieu European Journal of Social Work, vol 10, no 2, pp 225-43

Garrett, P (2017) Welfare Words:Critical Social Work \& Social Policy London Sage Giroux, H. (2011) Neoliberalism and the death of the social state: Remembering Walter Benjamin's Angel of History Social Identities: Journal for the Study of Race, Nation and Culture, vol 17, issue 4.

Goffman, E. (1963) Stigma: Notes on the management of spoiled identities New York: Simon \& Schuster.

Gottschalk, M. (2006) The prison and the gallows: The politics of mass incarceration in America, Cambridge: Cambridge University Press. 
Gupta, A. (2015) Poverty and shame-messages for social work Critical and Radical Social Work, vol 3, no 1, pp 131-39

Haney-Lopez, I. (2015) Dog whistle politics: How coded racial appeals have reinvented racism and wrecked the middle class, Oxford: Oxford University Press.

Hayes, D. and Spratt, T. (2014) 'Child welfare as child protection then and now: What social workers did and continue to do', British Journal of Social Work, vol 44, pp 615-35.

Howe, D. (2013) The compleat social worker, Basingstoke: Palgrave Macmillan.

Jensen, T. (2013) Riots, restraint and the new cultural politics of wanting Sociological Research Online, vol 18, no 4, p 7.

Jensen, T. and Tyler, I. (2015) "Benefits broods": The cultural and political crafting of anti-welfare common sense Critical Social Policy, vol 35, no 4, pp 1-22.

Jones, R., (2010) The story of Baby P: Setting the record straight. Policy Press.

Krugman, P (2015) The Austerity Delusion

https://www.theguardian.com/business/ng-interactive/2015/apr/29/the-austeritydelusion

Lipsky, M. (1980) Street level bureaucracy: Dilemmas of the individual in public services, New York: Russell Sage Foundation.

Link, B. and Phelan, J. (2001) Conceptualizing stigma Annual Review of Sociology, vol 27, pp 363-385

Mead, L. (1992) The new politics of poverty: The nonworking poor in America. New York. Basic Books

Morris, M., 2018. 'The way we are': Class and Britishness on film. Histories on Screen: The Past and Present in Anglo-American Cinema and Television, 3, p.65. Morriss, Lisa (2016a). AMHP work: dirty or prestigious? Dirty work designations and the Approved Mental Health Professional. British Journal of Social Work, 46 (3): $703-718$.

Morriss, Lisa (2016b). Being seconded to a Mental Health Trust: the (in)visibility of mental health social work. British Journal of Social Work. 
Munro, E. (2010) The Munro review of child protection interim report: The child's journey, tri.x, Policy briefing 11, available at: http://www.

trixonline.co.uk/website/news/pdf/policy_briefing_No-11.pdf

Murray, C.A. (1990) The emerging British underclass (Choice in Welfare), London: Institute of Economic Affairs.

Nozick, R. (1974) Anarchy, state and utopia, Oxford: Blackwell.

Oxfam (2013) The True Cost of Austerity and Inequality a UK Case Study https://www.oxfam.org/sites/www. oxfam.org/ les/cs-true-cost-austerityinequality-uk-120913- en.pdf

Parton, N. (2012) The Munro Review of child protection:appraisal Children and Society, vol 26, issue 2, pp 150-62.

Parton, N. (2014) The politics of child protection: Contemporary developments and future directions, Basingstoke: Palgrave Macmillan.

Peck, J. and Theodore, N. (2010) Recombinant workfare, across the Americas: Transnationalizing “fast” social policy Geoforum, vol 41, issue 2, March, pp 195-208. Perkins, A. (2016) The welfare trait: Hans Eysenck, personality and social issues', Personality and Individual Differences, vol 1, pp 172-8.

Piven, F.F. and Cloward, R.A., (1977.) Poor people's movements. New York: Pantheon.

Raco, M., (2012.)Neoliberal urban policy, aspirational citizenship and the uses of cultural distinction. In Contradictions of Neoliberal Planning (pp. 43-59). Springer Netherlands.

Sampson, R.J.,(2012.) Great American city: Chicago and the enduring neighborhood effect. Chicago University of Chicago Press.

Sayer, A. (2015) Why we can’t afford the rich, Bristol: Policy Press.

Shildrick, T. and MacDonald, R. (2013) Poverty talk: how people experiencing poverty deny their poverty and why they blame "the poor"'The Sociological Review, vol 61, no 2, pp 285-303.

Shoesmith, S (2015) Learning from Baby P London Jessica Knightley 
Simon, J. (2014) Mass incarceration on trial: A remarkable court decision and the future of prisons in America, New York: New Press

Slater, T. (2012) 'The myth of "broken Britain": Welfare reform and the production of ignorance', Antipode, pp 1-22.

Slater, T (2018) The Invention of the 'Sink Estate': Consequential Categorization and the UK Housing Crisis in I.Tyler and T. Slater (Eds) (2018) The Sociology of Stigma (London: Sage: Sociological Review Monograph Series)

Solomos, j (2014) Stuart Hall: articulations of race, class and identity, Ethnic and Racial Studies, 37:10, 1667-1675, DOI: 10.1080/01419870.2014.931997

Somers, M.R., 2008. Genealogies of Citizenship: Markets. Statelessness and the Right to Have Rights, Cambridge, Cambridge Cultural Social Studies.

Timmins, N., 2017. The Five Giants [New Edition]: A Biography of the Welfare State. HarperCollins UK.

Tyler, I. (2008) Chav mum, chav scum: Class disgust in contemporary Britain, Feminist Media Studies, vol 8, no 1, pp 17-34.

Tyler, I (2018) Resituating Goffman: From Stigma Power to Black Power in I.Tyler and T. Slater (Eds) (2018) The Sociology of Stigma (London: Sage: Sociological Review Monograph Series

Wacquant, L. (2007) Territorial stigmatization in the age of advanced marginality Thesis Eleven, vol 91, no 1, pp 66-77.

Wacquant, L. (2008a) Ghettos and anti-ghettos: An anatomy of the new urban poverty Thesis Eleven, vol 94, pp 113-18.

Wacquant, L. (2008b) Urban outcasts: A comparative sociology of advanced marginality, Cambridge: Polity Press.

Wacquant, L. (2009a) Prisons of poverty, Minneapolis, MS: University of Minnesota Press.

Wacquant, L. (2009b) Punishing the poor: The neoliberal government of social insecurity, Durham, NC: Duke University Press. 
Wacquant, L. (2010) Class, race and hyperincarceration in revanchist America Daedalus, vol 139, no 3, pp 74-90.

Wacquant, L. (2012) Three steps to a historical anthropology of actually existing neoliberalism Social Anthropology, vol 20, no 1, pp 66-79.

Wacquant, L. (2013) 'The wedding of workfare and prisonfare in the 21st century: responses to critics and commentators', in P. Squires and J. Lea (Eds)

Criminalisation and advanced marginality: Critically exploring the work of Loic Wacquant. Bristol: Policy Press, pp. 243-258.

Wacquant, L., 2016. Revisiting territories of relegation: Class, ethnicity and state in the making of advanced marginality. Urban Studies, 53(6), pp.1077-1088.

Warner, J. (2013) Social work, class politics and risk in the moral panic over Baby $\mathrm{P}$ Health, Risk \& Society, vol 15, issue 3.

Warner, J. (2015) The emotional politics of social work and child protection, case of human rights Bristol Policy Press

Webb, S.A., (2006) Social work in a risk society: Social and political perspectives. Palgrave Macmillan.

Webb, S. (2010) (Re)Assembling the Left: The politics of redistribution and recognition in social work British Journal of Social Work, vol 40, pp 2364-79. Welshman, J. (2012) Underclass: A history of the excluded since 1880 London Bloomsbury 